\title{
DEVELOPMENTS IN EASTERN COUNTRIES AND THE EAST-WEST RELATIONS
}

\author{
Doç. Dr. Haluk GÜNUGUR*
}

\section{INTRODUCTION}

Our world has been undergoing radical changes over the past few years. Militarymachines, which under the "Warsaw Pact" and NATO Treaty, used to divide the world into two opposing camps, have now yielded their place to a more or less perpetual 'detente'. Couniries formerly hostile, especially in Europe, are forming economic, and in some respects, political partnerships, and ever closer cooperation now exists between "yesterday's enemies", especially in Europe. The term "East-West" which used to signify political division, is tending now to indicate purely geographical separation.

In this worldwide political context, in the first part of this study we shall try to examine very briefly, the developments in the Eastern European Countries. In the second part of this study, it will be taken into consideration not only political, but also economical relations between Eastern and Western World. In conclusion we shall try to bring some considerations in terms of the pace of Turkey in the East-West relations.

\section{I- DEVELOPMENT IN THE EASTERN COUNTRIES}

\section{a- POlitical and Structural Changes}

It is extremely hard to keep in step with the speed of the events which occur in East Europe in the last couple of years. The threat balance which appeared after the 2 nd World War and kept its affest about 45 years, has left its place to mildness and warm cooperation. In the source of the events, which have firstly started in Poland and Hungary and spread over the other Eastern European Countries with high speed, the desire of transfer to the classic Plurality Democracy Model and Free Market Economy in the western meaning from the "socialist political and economic model" which was used for many years and was finally bankrupt is present. Beside this fact, "nationalist movements" is also one of the basic reasons of the radical changes in these countries.

\footnotetext{
*Gazi Universitesi lktisadi ve Idari Bilimler Fakültesi Ogzretim Oyesi
} 
Some of the steps in the East Jituropean countries in order to be democratic were exteremely bloody and the action ritd a public movement appearance from bottom to the top (Romania, Czechoslovakia, F'(uliand and.Baltic States). Contrary to these, the change period was from the top to the rttom in some countries. From all point of views, however, all of the above moverr crits towards democracy, human rights, liberty and free market economy in Eastern Euri) ye, are the direct result of the "green light" given by Mikhail Gorbachev following the famous glastnost and perestroika policies, which opened the new horizons to those: countries... 'Ve realise that it is not easy to outline all these events; however, we shall try to summarise them as they affected each country.

\section{Poland}

Poland led the democracy risvement ten years before the others, with its famous "Solidarity" concept. However, d:ınocratic aims remained unsatisfied between 19801981, the Solidarity Trade Union $x$ as disbanded, and martial law imposed. For the first time, the EC took the position farsiring the Eastern Europrean countries during the polish crises 2 . The country's cornmunis. overnment unable to cope with the adverse economic and social situation that ensued, .urned to "Solidarity" in late 1988 to help solve the crises. Agreement was reached ir April 1989 racognising, "Solidarity's" legality, and for multi-party elections to be held. [iespite efforts by General Jaruzelski former Polish president, and First Secretary Ger rial of the Polish Communist Party, Lech Walessa was elected President of the Republic: ir Jecember 1990.

Immediately after his election as the president, Mr. Walessa came to Brussels to ask the Commission to arrive a "Eurcflean Agreement" as soon as possible. On the same occasion, he pointed out that "? Jland is not asking for a hard-out but looking for Christopher Colombus who will disover a potish business market ${ }^{1}$.

Poland has introduced the mcst radical economic reform programme up to-date. In the short term, this has caused living standards to fa!l and unemployment to rise. However, since the programme': introduction, food supplies have improved and the external account has a surplus. Cur endy Poland has a very high inflation level ${ }^{2}$, and one of the highest foreign debi among Zastern Europe, at over $\$ 40$ billion (US Dollars 1078 per capita) ${ }^{3}$,

The recent and democratic elec ions were held on 13 October 1991, and the results, and ensuing parliamentary seat dist:iijution are as follows :

\footnotetext{
1Walessa L., Agence Europe, 4 4.1992, p. 5.

${ }^{2}$ Günuğur H., "Dörth Beş, Alsı, Polenyła Battı", IT'O, Istanbııl, 31.5.1991.

${ }^{3}$ La Communaute et se: Voisin; de l'Est, pub. CE, 8/1990, p. 23.
} 


$\begin{array}{lr} & \text { Seats } \\ \text { Democratic Union } & 62 \\ \text { Democratic Left } & 60 \\ \text { Catholic Action } & 49 \\ \text { Confederation of Independent Poland } & 46 \\ \text { Democratic Liberal Congress } & 37 \\ \text { Total } & 254\end{array}$

\section{Hungary}

Hungary was the most persistent economic reformer of the entire Eastern Bloc. The Communist Government, which took over after the brutally suppressed 1956 uprising, made a conscious choice to give priority to improving living standards. Initial efforts to open the economy date from 1968, but these and subsequent efforts frustrated partly, because of the inadequacy of reform measures and partly because of external payments constraints.

Hungary has the highest level of foreign debt in Eastern Europe, at a level of \$ 1900 per capita. The economic reform process has been less turbulent here than elsewhere because of the earlier moves towards liberalisation. Foreign investment has been encouraged and privatisation of the economy is under way. Democratic elections took place in March/April 1990, as follows:

$\begin{array}{lrc} & \% & \text { Seats } \\ \text { Democratic Forum (Centre Right) } & 25 & 165 \\ \text { Free Democrats (Liberal, Centre) } & 21 & 92 \\ \text {. Independent, Proprietary (small party, Agriculture) } & 12 & 43 \\ \text { Socialist (Former Communist) } & 11 & 33 \\ \text { Others } & 31 & 53 \\ \text { Total } & 100 & 386^{4}\end{array}$

After these elections, Government headed by Democratic Fonum supported by Small Proprietary Party and Christian Democratic Party, was established ${ }^{5}$

\section{Czechoslovakia}

Czechoslovakia is the most highly industrialised country in Eastern Europe, and, prior to the Communist regime, had a very strong democratic tradition. In the thirties, its standard of living could be likened to that of Switzerland ${ }^{6}$, when the communists handed over power in June 1990, Vaclav Havel, most prominent figure in the Civil forum, was elected President of the Republic. Dubcek, former First General Secretary of the

\footnotetext{
${ }^{4}$ Ibid, p. 255

${ }^{5}$ Hungarian philosopher Miclos Gaspar Damas stated that, concerning the democratic elections "What is happining in Hungary is not a reform but a revolution", cited by Gazzo E., Agence Europe 17-18-4-1989, p. 1.

${ }^{6}$ The Community and its Eastern Neighbours, Pub. CE, 1991, p. 5.
} 
Communist Party before 1968, $s$ it to Turkey as Ambassador after Russia's brutal military intervention, was clected Pr ssident of the Parliament:

As a federal state, C:echoslovakia is composed basically of two states, the Czech and the Slovak, with a Chimber of the People and a Chamber of Nations. There are 150 seats in the First Chamber (101 for he Czechs, 41 for the Slovaks), and 150 seats in the second (each State having 75 ). The $\$ 90$ election results are as follows :

Civil Forum (Alliance, Anti C.jmmunist, Czech and

Slovak)

Communist

Christian Democrat

Autonomists (Moravia, Silesia)

Slovak National Party

Others

Total

\section{Seats}

87

23

20

9

6

5

150

Because of the relatively harnunious way in which it has carried out democratic reform and because of its industrial pritential and traditions, Czechoslovakia is considered one of the Central/Eastern European countries best placed to make the change to a market economy. It has a favourable geogiaphical position and highly qualified workforce. Even if old-fashioned, the country's infras'ructure is less damaged than others in the Region, and has functioning car, mechanical, glass and shoe manifacturing industries. The new reform package contairis enterpris : privatisation, the opening to foreign investment, public spending reductions, and the llandoning of the state planning economy.

On 29.4.1991, the sredit a.s cement (middle term) has been signed between Czechoslavakia and the EC. This ilgreement provides 375 millions ECU to settle the balance of payment. This amount ' $A$ ill be given in the framework of the credit promised by the Group of 24 ( 1 billion dollar $; i^{7}$.

\section{Romania}

Deyelopment towards demor, acy has been more difficult, and has caused more bloodshed in Romania than in other iastern European countries. The Ceaucescu dynasty that ruled Romania oppressively for Inany years with the aid of the dreaded secret police (Securitate) was first challenged b:! Transylvariaans of Hungarian origin in Timisoara. These developments escalated, axd leading to the executions of dictator Nicolae Ceaucescu and his wife Elena. This ias confirmed predictions that Romania will be the country of Eastem Europe to ex]):rience the nost difficulty in restoring democratic traditions and political and econor. $\mathrm{i}$; stability.

The rebuilding of political arc iconomic slructures will take much time and could lead to considerable instability. Because of its totalitarian past, few individuals have the legitimacy or credibility to lead th s country forward. Romania's one bright spot is its

${ }^{7}$ Agence Europe, 30. 5. 1991, p. 11 
negligible foreign debt (around $\$ 1$ billion, or US\$ 44 per capita). For this reason it will be easy to access international credits in support of a reform programme. On the other hand, the country's human potential is not sufficiently experienced to put this reform programme into place.

However, elections were held in May 1990, with the following resuits :

$\begin{array}{lrc} & \% & \text { Seats } \\ \text { National Front (Former Communist Army Officials) } & 66 & 233 \\ \text { Democratic Union (Hungarian) } & 7 & 29 \\ \text { Liberal } & 6 & 29 \\ \text { Green } & 3 & 12 \\ \text { National Party (agriculture) } & 3 & 12 \\ \text { Others } & 15 & 81 \\ \text { Total } & 100 & 396\end{array}$

As can be seen, the country is still being governed by the former Communists.

The EC has given in the framework of the program (PHARE) some 25 millions ECU for reenforcement of private sector in this country ${ }^{8}$. In the other hand, we must remember that even if Romania receives some economic support from the EC, it is not yet a question of opening the negotiations for an association or European agreement. However, Roman minister Dijmarescu declareted that "Romania would like to be a member state of the Community", during his visit to Brussels?.

\section{Bulgaria}

The dramatic developments elsewhere in Eastem Europe also reached Bulgaria, where conservative communist leader, Todar Zivkov, was forced to withdraw from the political arena. Bulgaria is the Eastern European country whose economy was the most closely linked with that of the Soviet Union and former Comecon partners. It will therefore take a long time to reorient its economy towards a free market, and the country's reform program is slowly being put into operation. Bulgaria is basically agricultural, with no major industry; because of this, it will need additional aid and foreign investment from the western world to enable it to reach free market rules.

The 1991 elections saw victory for Union of Democratic Forces. Election results and the actual seat distribution at the Bulgarian National Parliament are as follows:

Union of Democratic Forces

\% Seats

Socialist Party

$45.8-110$

Movement for the Rights and Frcedoms (turkish minority party)

$44.2 \cdot 106$

Total

$10 \quad 24$

$100 \quad 240$

${ }^{8}$ Agence Europe. 1.5.1991, p. 6

${ }^{9}$ Agence Europe, 1.6.1991, p.8 


\section{Former German Demırratic Republic}

Not much need to be said, sinc: after reunification, the G.D.R. became the eastern region of the Federal Republic of Jermany. In fact, we do not consider this as a "unification" but as a "participation ita the west", since Germany's constitution does not recognise the country's division. Of irially, since 3 October 1990, the G.D.R. no longer exists 10 .

\section{Yugoslavia}

This country has traditiona ly enjoyed privileged relations with the Western European countries. This was largey due to its refusal to join the Soviet Economy and the military sphere of influence, $b_{11}$. also because its particular brand of economic selfmanagement was seen at one stage as a potenlial third way, between rigidly planned communism and the market econorry. In 1989 inflation exceeded $1000 \%$. An economic reform program, including the pegis $\mathrm{r} g$ of the Dinar to the Deutschmark, was introduced in 1990. The EEC is keen to continue its assistance to Yugoslavia (900 million Ecu 1991-1996). However, outside help for political and economic reform process from the EC or elsewhere is handicapped by' the internal conflicts between Slovenia, Croatia and Serbia.

Federal Republic of Yugoslay a has already been disintegreted First Slovenia and Croatia proclaimed their independe r c s on 25.6.1991 11 . The efforts of European Political Cooperation in terms of "Troika" ar C Brioni Agreement have not succeeded in bringing peace to this country ${ }^{12}$. Then Maz sionia and Bosnia-Herzgovina followed these two republics. The independence of Slc venia and Croatia has been recognized by Germany and the EC Countries at the end of last year. "Turkey, on its part, has recognized on february 6 1992, not only the two christian originated republics, but he has also recognized the other two republic:s where mosicms are in majority and more than one million Turkish originated pcople riside. This approach is an indicator of the objective foreign policy which has been rraintained without race discrimination and equal application to such countrizs. This $\mathrm{J}$ )icy has been greeted by pleasure and enthusiasm in all the countries which announces their ind:spendency especially in Macedonia. Recognition decision will maintair, toth econonic and politic benefits of Turkey in the coming years.

Actually, the situation in Ecsnia - Herzegovina is more than tragic. The yugoslavian national army intensiliss its violence and aggression against even civil population living both in capital an: in rural arca of this country, in spite of the peace efforts taken by the international organizations: including united - nations and some individual states in Europe, this civil war hasn't been found a solution. It is not possible to consider this fact as ar, "interni. iffairs" of :ome country. Because, this war has a potential to threat not only curope: 1 , but also world peace. It would be imperative that

10 For fuller details conceming Germ in reunification, sce Günuğur H., "I come from Berlin". Iktisat, Ankara 22.10.1990 (in turk:ish)

11 Agence Europe, 27.6.1991, p. 3

12 For fuller details see Günugur H., "roika will rot Bring the Peace in Yugoslavia", ITO, Istanbul, 19.7.1991 (in turkish). 
the CSCE and the international community act more efficiently in this conflict and bring some radical solutions to Bosnia - Herzegovina question.

For its part, Turkey is actually playing very dynamic role at the intemational platform concerning Bosnia - Herzegovina problem. Following the proposal of turkish delegation, the fifth extraordinary session of the islamic conference of foreign ministers held in Istanbul June, 16-17-1992, strongly condemned the aggression against the republic of Bosnia - Herzegovina, and expressed its alarm at the critical situation arising from the acts of violance perpetrated by the yugoslavian national army and serbian irregular forces, assisted and encouraged by the serbian leaderships.

\section{Albania}

Albania resisted the move towards democracy until the end of 1990, when some slow movement loward reform was started. The Communist party authorised the creation of other political parties, and the Government was obliged to abandon its traditional political and economic isolation.

Currently Albania is undergoing very difficult internal political problems, and, during April - August 1991 period, over 50.000 Albanians escaped to Italy, where, in turn, they created some political and social problems, and elsewhere in the EC countries $^{13}$. On the other hand, the EC decided to give Albania some food aid (100000 tons wheat), and study the possibility of including this country to the PHARE program ${ }^{14}$. Moreover, Albania was accepted as a member of CSCE on 19.6.1991. Today the number of the CSCE members reached 5215 .

\section{Soviet Union}

All of the above movements towards democracy in Eastern Europe are the direct result of the "green light" given by Mikhail Gorbachev who originated "Glasnost" and "Perestroika" policies which so inspired the east with a new "structural spirit". The speed with which the events of late 1989, early 1990 took place could never have been anticipated.

Why didn't Gorbachev sound the alarm while the European Community was preoccupied with the 1992 Single European Act? Why did he stand behind the people of Eastern Europe rebelling against their countries' regimes? Could it have been that he really supported their actions voluntarily, or that he was aware of the limits of his powers to prevent the movement, and did not therefore dare to counter - act.

These questions are unanswerable. Perhaps in the future, even Gorbachev himself might regret Glasnost - whether he likes it or not, the Iron Curtain has now been

${ }^{13}$ Belgium did no: grant the status of political refugee approx. 12 albanians (a negligible number). whereas, hypocritically submitting to the Security Council in April a plan for Turkey to accept as "political refugees" the 400.000 Kurds who had escaped from Saddam Hussein'n appression just after the end of the Gulf War.

14 Agence Europe, 31.8.1991, p.5

15 On 1.7 .1992 
breached; in fact it is no longer rially feasible ro talk about an "Iron Curtain" - rather, a "net curtain" exists between East ind West 18.

During the period where the Eastern European States were following the democratisation and the reform \%ocess in their respective countries, the separatist nationalist movements started in those republics which would eventually cause the disintegration of the S.U. This revolt started first in the Baltic States and spread to other States, especially the Cancasus re fublics. It was difficult for Gorbachev to control those nationalist rebellions and the "Sov et unity"

Moreover, the economic situation of the whole Soviet Union was nearly catastrophic. It was very' difficu it for soviet people to find basic food. The danger of shortage arose. Inflation galloped 3 3cause of this terrible economic situation, Gorbachev has been cruelly criticized by the $)$ sople now as:serting their newly discovered democratic rights.

The situation even on the international sphere was not very optimistic for Gorbachev. Even if he got the promises of Western World, thanks to his popularity, he did not achieve concrete results. I 1 ; returned from the $\mathrm{G}-7$ summit held in London on July 1991 "empty - handed"16. is a consequence, he become more and vulnerable against his conservative commun ist rivals in tht; party and also reformist Yeltsin.

In this hopeless picture, on 19th August 1991, the conservative communists have obtained power in S.U. by the "coup d'Etat". "The committee headed by vice president Yanaev, composed of 8 persons (i kiluding Rec. Army and KGB leaders) resisted only 3 days, and was then obliged to 3 zie up power thanks to the efforts of Yeltsin, and democratic forces. After some tiree, and against the wills of Gorbi, three Slav States proclaimed, on 8.12.1991 the creation of "Community of Slav Nations" in Minsk 17 . This proclamation was only some steps towards the dissolution of the Soviet - Union and, at the same time the establishment of the "Commonwealth of the Independent States" which have been created at the end of last year, in Alma - Ata ${ }^{18}$. Recently, the Independent States adopted also, the "treaty of non-aggression" among them, in Minsk (15.2.1992) and recognized the conirion borders.

\section{B- ECONOMIC OLTLOOK OF EASTERN EUROPEAN COUNTRIES}

It is not easy to oblain recert information about economic indicators for Eastern European countries However, the following indicators can be provided conceming the last 8-10 years period, from CIECD sources :

${ }^{16} \mathrm{Mr}$. Primakov, special delegate of Corbachev sent to London for the first contacts with G-7 pointed out that "the canger of sicial revolt in Soviet Union would be in question. If Gorbachev could return to Mosk.c v from London emply - handed..." Agence Europe 15. 16.7.1991, p. 2

${ }^{17}$ For further details, see Günuğur., "S.U. Disintegrated", Milliyet, Daily Newspaper, 12.12.1992

${ }^{18}$ For Further details, see Günugur H., "Spirit of Alma-Ata". ITO weekly Newspaper, 27.12.1991 


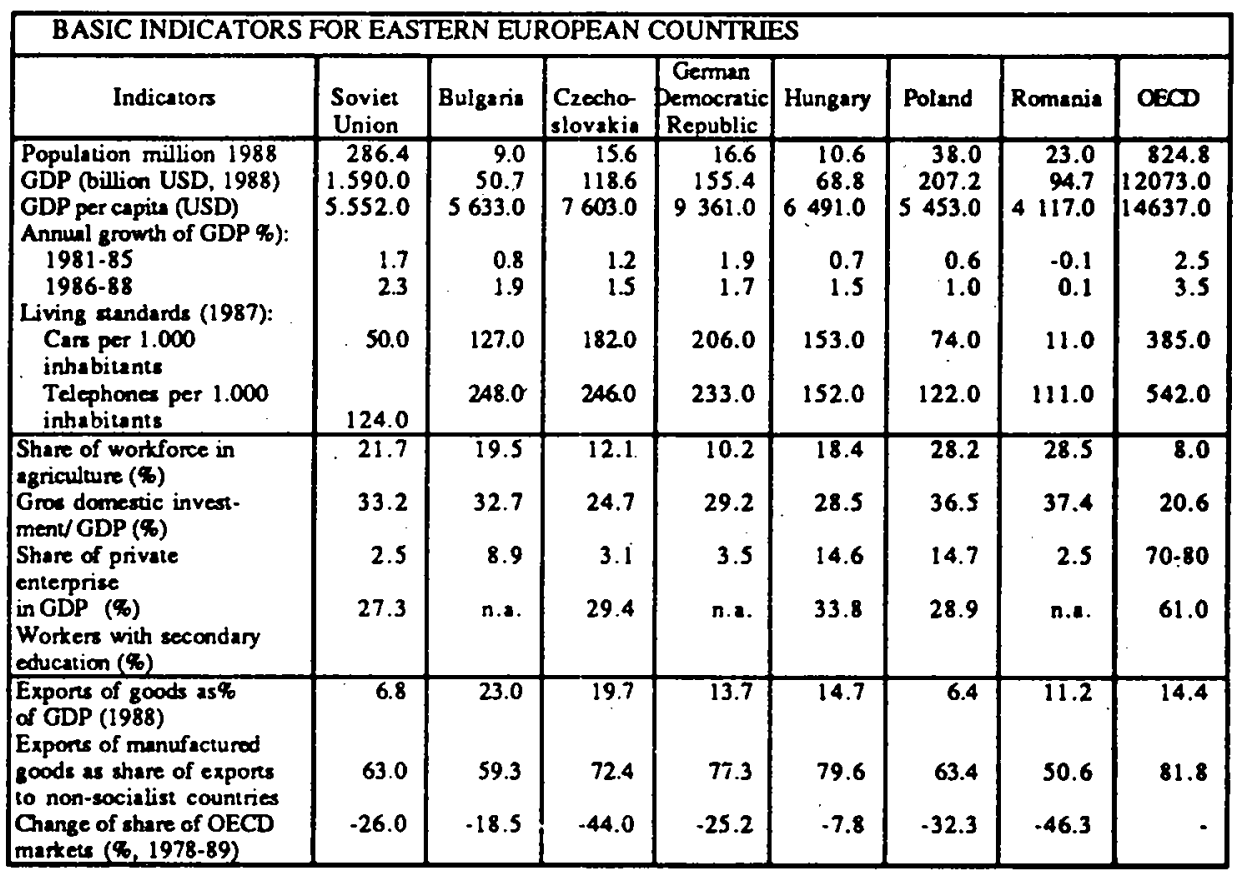

With the exception of Romania, all these countries have considerable foreign debt, both to international financial organizations and also to private banks. According to World Bank sources, Eastem European countries' foreign debt picture is as follows :

$\begin{array}{lcc} & \begin{array}{c}\text { Foreign Debt } \\ \text { Total }\end{array} & \\ \text { POillion US\$) } & \text { PER CAPITA (US\$) } \\ \text { HUNGARY } & 40.4 & 1.078 \\ \text { CZECHOSLOVAKIA } & 19.7 & 1.873 \\ \text { BULGARIA } & 6.9 & 431 \\ \text { ROMANIA } & 9.5 & 1.056 \\ \text { YUGOSLAVIA } & 1.0 & 44 \\ \text { SUG } & 17.6 & 733\end{array}$

Sources : World Bank, IMF

Trade relations between the Twelve and Eastern European countries are not favourable to the latter. With the exception of Hungary and Bulgaria the commercial balance is uncovered. According to Eurostat sources, the following table indicates the trade balance between EC and Eastem European States. 
COMMUNITY (EUR 12) TRADE 1 'ITH EAST I:UROPEAN COUNTRIES, 1986-88

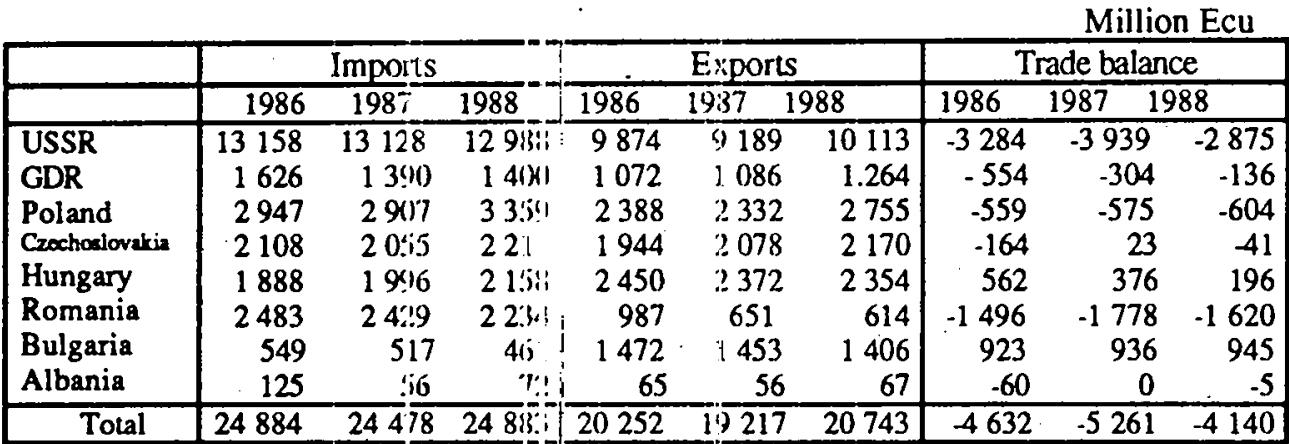

(Source : Eurostat)

The table shows that, on a broz 1 range of economic and social indicators, there is disparity between the Eastern and Wøs:ern countries. As we can observe, those countries need considerable financial suppor irom the West, links promise of aid to continuing democratic and economic reforms in t.32se countrics ${ }^{19}$.

\section{RELATIONS BETWEISV EC ANI) EASTERN EUROPE}

\section{A. IN GENERAL}

The principal Preoccupation of tre Western World in the framework of East-West relations is the non-application by the new States, of the international agreements concerning the nuclear weapons sign $\geqslant 1$ by the former USSR, and the security question. Nevertheless, the presidenis of the Independent States, having the nuclear weapons, clearly declared that, they will respe:: he agreements on this issue already signed by the former USSR.

For its part, the European Corrmunity, in the context of EPC, adopted a certain number of declarations and statemems concerning East-West relations. The declarations and statements reflect the commor cpinion of the "Twelves" on the political events which take place in the Eastern Eunopean countries during the last years (The EPC, which was administered with lack of legal base bifore the entry into force of the Single European Act, was reached its legal til.e after the entry into force of the SEA on July 01 $1987^{20} \mathrm{EC}$ countries have reinforced the movements for democratization and transfer to the free market economy brth in the: Eastern Eurcpean Countries and the former USSR by means of the declarations: they hav: agreed in the framework of the EPC.

The European Commisision adc t ted and forwarded to the Council a communication on the Community's relations with the Indeperdent States of former USSR. This

\footnotetext{
${ }^{19}$ For further details concerning the $W_{1}: \leq t e r n$ aids, see: Adda $J .$, Colin R., "L'Europe entre l'Est et le Sud"in Observations et Diagrinstiques Economiques., Rev. de I'OFCE, no 32. 7 1990, p. 150

${ }^{20}$ Louis J-V., "Cooperation Politique Evropeenne et la Nation Unies", pub. ULB, Bruxelles, 1990, p. 8
} 
communication notes that "the fundamental change resulting from the dissolution of the Soviet Union, the annoucement of the creation of a Commonwealth of Independent States (CIS), and the effective exencise of soverignty by the Independent States requires a reexamination of the Community's policy". In this regards, Commission considers that :

-regarding the recognition of the new States, the Council defined a code of conduct on december 16 last year which must be applied with a view to recognation and the establishment of diplomatic relations.

-support actions (emergency aid, food aid, technical assistance) must be continued, strengthening coordination with the USA, other donner countries and international organizations.

-a new approach is needed in regard to future relations between the Community and the new Independent States.

Vice president, responsible for external relations, Mr. Andriessen outlined to the press the main points and the reasons for the new approach. He said that :

-simple trade agreements or first-generation cooperation agreements are insufficient in regard to States which have entered into the democratic process and the transition to a market economy.

-association agreements of the kind the Community has already concluded with Hungary, Czechoslovakia and Poland cannot be envisaged at least for the time being, for three reasons.

1- The new Independent States do not yet fulfill the required political and economic conditions and the overly hasty extention of association countries barely in the first stage of reform would water down the political interest and significance of association.

2- Association agreements include a timetable for the complation of a genuine free trade zone, which cannot yet be considered in these cases.

3- Association agreements include an explicite reference to the objective of the assession to the Community which would be inadvisable with regard to countries for which it is premature to say wheather such an objective is of interest (in the case of the republics located outside of Europe, it is a priori excluded).

-an intermediate type of accord between trade and cooperation agreements and association agreements will have to be provided. The Commission considers that the approach taken to the cases of the Baltic States and Albania could serve as an example. This type of accord should enable the broadest possible opening of markets, far-reaching cooperation, a framework of technical assistance, support for the democratic process and, for the countries which can subscribe to the Helsinki Agreements a political dialogue 21 .

${ }^{21}$ Andriessen F., EC News, 1.30.1990 Ankara, p. 6 
The Commision will therefore as: the Counzil to take note of its plans to enter into exploratory discussion with son : of the new Independent States Mr. Andriessen stated that priority would loyically be given to the republics the European Community has already said it is preparec to recog, i. $\mathrm{ze}^{22}$. He added that a single model of agreements identical for all the republics would $10 t$ be considered. He considers that the EC has greater responsibility in regard to the rejublics located on European territory and that this is an aspect that cannot be neglected 23 .

It is not possible to consider Ecst-West relations outside of the "Conference on Security and Cooperation in Europe' (CSCE) context. This field contains a vast sphere of experience to talk with "one voice" curing the 4 years of negotiation of the "Helsinki Final Act" 24 . Community States maintained a united front on all essential points. It was this that EC countries discovered he potential of the political cooperation 25 . The Twelve try to take "commor. position" not only concerning the East-West relations, but also in the framework of the internatio cal organizations, especially United-Nations ${ }^{26}$

\section{B - INDIVIDUAL \$TTEPS 'TWARDS EC MEMBERSHIP}

The Eastern European countries are willing to take part in the future "European construction". Some of ther, imagint: in a very short period joining to EC, some others prefer to wait for some time.

Immediately after its victory at folls in April 1990, Hungary's Democratic Forum, which headed the winning coalition, said that membership to the European Community would be the new government's prior $t y$ in foreign policy. Leaders of other Central and East European countries havis made siunilar statements.

The European Community is il magnet for East European reformers. This is because of the Community's record ol democracy and balanced economic growth. Their aspirations to belong to such an o:cler are legitimate. But there is also a necessary element of self-interesi. East European will make it more difficult for them to export to the EC.

The Community is aware of the a.jpirations and concerns of Eastern countries. But early membership to the EC is exclucled for many reasons, both economic and political.

\section{C- CONCLUSION OF EUROPEAN AGREEMENTS}

European Agreements betweer. the EC and three eastern european countries, i.e., Poland, Hungary and Czechoslovakia are to consist of four essential elements:

a-Free trade between those courtrizs and the Community,

22Further details, see Agence Europu:, 1.3.1992, p. 4

23 Ibid, idem.

24 July 1975

$25_{\mathrm{EPC}}$, European File, No 13/88, Erirelles, 1983. p. 5

${ }^{26}$ For the EPC in the Framework of :1.. U-N, sec Dever E., "intervention" in la CPE et la N-U., pub. ULB., Bruxelles, 1990, F. 25/32, and Fonder H., Ibid, p. 33/35 
b-Industrial, technical and scientific cooperation,
c-Programme of financial assistance,
d-Creation of a mechanism for political dialogue.

The agreements do not mean a transitional period to become member of the EC. However they do not exclude the possibility to join the Community 24 . But this possibilty would be conditional on intemal progress by those countries in the area of the rules of law, the respect for human rights, the maintenance of a pluralist democracy and economic liberalization.

\section{1- Free trade}

The aim of the agreements is to bring about the phased introduction of two-way free trade. The step-by-step approach will take account of the specific reforms under way in each country as they concern prices, subsidies, taxation, monetary policy, currency compatibility and its system of foreign trade. The aim of the reforms is to align their national systems with the open system of multilateral trade and global competition.

In moving towards the free-trade objective, the Community will reduce its tariff and other import barriers more rapidly than partner countries. Associated countries would open their markets for Community goods according to a flexible timetable and one which reflects their specific situation.

\section{2- Economic and technical cooperation}

This cooperation will reinforce the structural changes undertaken by those countries, contributing to their integration into the world trading system. Prime focus will be on measures to facilitate technology transfer and direct foreign investment.

\section{3- Financial assistance}

The community will offer a set amount of credits for each country to finance cooperation and technical assistance. The Community is already committed to spending 2 billion ECU in assistance to Central and East European countries in the period of 19901992.

The financing of projets which promote investments in the private sector will benefit from a particular priority. Financial assistance will take the form of subsidies (technical assistance, interest rate rebates) or loans (European Investment Bank, European Coal and Steel Community, Euratom) or risk capital and other instruments.

\section{4- Political dialogue}

The european agreements will provide the institutional framework for a political dialogue between the EC and each of its partners. A Council of Association will be created for each agreement in which the Community and individual partners will discuss and decide on issues of mutual interest. A structure will be created for cooperation between the European Parliament and the national parliament of each associated country. 
The European Community $t ?$ ? to help those countries, but real efforts must be spent by temselves, as the vice-p esident of the CE Commission mentioned; "The European Community is villing to accept its c(i-responsibility for what is going on in these countries. But it should also ba made clear that our assistance cannot fully replace the responsibilities to be assumell by the individual countries themselves. To put it another way we can do no more thiul 'ielp them to help themselves".

In addition, the touctistone for regotiation and implementation of such agreements will be the degree of progress on phlitical and economic liberalization achieved by the individual countries. Such cosidiations have already applied in the decisions the Community has taken to accelerille the elimination of import quotas on Polish and Hungarian goods in the first-generation agreements with these countries and to up-date the very limited 1988 agresment wit 1 Czechoslovakia.

To quote Mr Andries ien again: "In the view of the EC, there should be irreversible trends for real democracy and an opening to a market economy in the particular country concerned before an association afris r.jent can be put into place 27 "

\section{D- ECONOMIC IND TECHNICAL ASSISTANCE}

\section{Assistance in Short T'rm}

In the light of these constraints, the Community has focused on short and medium term support for the reforn process $€ S$ which are under way. It has taken steps to open its markets to East European exports, and has put in to place a range of actions and programmes both on its own initiative and in cooperation with other Western countries.

The Phare program, which $t / 1$ : Commission is coordinating on behalf of the 24 donnor countries is the most wide-ranging. The Community has made the continuation or extension of its aid conditional on tine consolidation of democracy and progress toward a market economy.

The Central and East. European States have met the challange. Democratic multi party elections have been held in all of them expect Yugoslavia. All have begun implementing programs to liberalize and privatize their economies. The Community has taken immediate action to support c fforts to develop market-oriented policies, to grant these countries better acces to Weste $\pi$ । markets, to provide financial aid to offer technical assistance and training, as wcll as $w$ facilitate for ign investment.

\section{2- Assistance in Long Tein}

The Community is taking a ks:? iole in coordinating the overall Westem aid efforts for Central and Eastem Europe. Tixse efforts are centred on the Phare and Tempus programs and the creation of a Elusopean Bank for Reconstruction and Development

${ }^{27}$ Andriessen F., "Europe at the Crussroads : the EC in a Changing Political and Economic Environment", speech delivered in Firussels, 8.6.1990, European doc. 8-90, p. 15. 
(EBRD). The inital success of those initiatives in support of reform and restructuring in Poland and Hungary has led to its extention to the rest of Central and Eastern Europe.

\section{The Phare Programme}

The Phare Programme was set up by the Group of Seven summit in Paris in July 1989. The summit charged the European Commission with coordinating assistance from the Group of 24 Western industrialized countries taking part in the program 28

This function enabled the Commission to take on a new and important international political role. For, besides coordinating Western aid, it has increasingly taken the lead in framing Phare policy and strategy. The initial aims of Phare were to sustain the political and economic reform process in Poland and Hungary and in particular to strengthen the private sector.

The priority areas identified by the Commission, in consultation with the IMF, the World Bank and the OECD, are now the object of substantial programmes. These areas are agriculture and rural development enterprise restructuring, .banking and finance, investment, the enviroment and professional training and technical assistance.

In addition, the G-24 countries have taken action to facilitate access to Western markets for Polish and Hungarian exports. They have removed quantitative restrictions on Polish and Hungarian products, extended most-favoured nation status (where this was not already granted) and extended to them their system of generalized preferences.

The Community and its G-24 partners have also provided financial safety nets Poland and Hungary in the form of the Polish Stabilization Fund and the Community's medium-term loan of USD 1 billion to Hungary. The Stabilization Fund has helped underpin Poland's radical reform programme which might have otherwise proved too risky. This programme has reduced inflation, strengthened the zloty and improved the balance of payments.

The medium-term loan has helped maintain Hungary's access to international capital markets and encouraged other institutions to provide finance for economic restructuring.

The Commission fixed the new assistance programme in the framework of phare in 1991 and $1992^{29}$. On the other hand, there are some problems for giving aid to Bulgaria and Romania ${ }^{30}$. However, Mr. Andriessen stated that the Commission plans to negotiate with those two countries the association agreements ${ }^{31}$.

${ }^{28}$ The G-24 consists of the 12 EC countries plus. Australia, Austria, Canada, Finland, Iceland, Japan, New Zealand, Norway, Sweden, Switzerland, Turkey and the US.

${ }^{29}$ For distribution of this aid, see Agence Europe, 17.5.1991, p. 11-12, and also Agence Europe, 3.8.1991.

30 Agence Europe, 22.8 .1991 p. 3

31 Agence Europe, 13.6.1991, p. 6 


\section{The Tempus Programme}

The Community has invited thi: cther G-24 inembers to participate in the Tempus Programme for student exchanges ar $c$ in the Europrean Foundation for Training. Tempus was formally established by the Comununity in May 1990.

With funding of ECU 117 mill.crr., Tempus is a three year programme whose main purpose is to finance acadeınic exchanges to enable students and teachers from Eastern Europe to spend up to a year at an E:- university or in a company or administration. A smaller number of teachers and studer t L: from EC universities would send equivalent time in Eastem Europe. Tempus: also promotes exchanges between Eastem universities or private businesses in the EC.

\section{The European Bank for IR a:onstruction and Development}

The creation of the E:BRD is :te Commurity's main multilateral initiative for Central and Eastern Europe. It was $f \mathrm{r}$ it proposed by President François Mitterand in a speech to the European F'arliameir: in Septem jer 1989 and endorsed at the EC's Strasbourg Summit in December of iat year.

It has been extended to the G- $2<$ !hare net-work and beyond to include the Central and East European countrie; and the is)viet Union as well as other members of the IMF. The Community and its Member Stutes have a majority stake in the EBRD which has a share capital of ECU 10 billion. In all, there are 42 members - 40 countries plus the Community and the European Inves:Inent Bank. The Bank will play an important role in supporting productive inves:ment in the private sector and in related infrastructure.

According to the first article of th: EBRD's satutes,

"The purpose of the Ba.7k shall be to foster the transtion towards open market-oriented economies and to promote private and enterpreneurial initiative in the Cent: 1 and East Furopean countries committed to and applying the principal: : of multiparty democracy, pluralism and market economics."

The seat of the Bank is Londor. Its President is Jacques Attali, former adviser to François Mitterand.

\section{CONCLUSION}

As we can observe, since some years the Eastern countries are undergoing a very rapid change towards a classic deir ccracy based on human rights which is political model, and free market economy whic n is economic model. This devepoment is actually irreversible. However, thes a countrics, including Commonwealth of Independent States (CIS) need long time to estiblish the: rial structure permitting to apply correctly the rules governing those two models. The Fiıropean Community and the Western World try to give them considerable support witl abjective. Nivertheless it is not evident to say that the programmes (Phare, Tempus evin creation of the European Bank for Reconstruction and Development) are sufficient to sclve all cconcmic problems of these countries. Now, Western European countrics don't cel any threat both in political and military sphere 
coming from the East. Therefore, the West must pay the "price of detant" and the lasting peace in Europe.

The EC already concluded "European Agreements" with Poland, Hungary and Czeshoslovakia. The European Agreements provide a possibility for those three states to join EC. However, this participation would only be realised in the beginning of next century. In other words this is only long term perspective.

But in short term, Eastern countries need (especially new Independent Republics) basic food and medical assistance. For this purpose, the intemational aid, to the Commonwealth of Independent States in general and to the 6 Turki Republics in particular which are in economic difficulty has been started via Turkey or through the initiatives of Turkey. By means of this operation, known as "provide hope", medicine and food aid are executed by means of the planes which take off from Turkey. In the ceremony, made for the operations, started on February 101992 by 7 airplanes, Turkish Prime Minister Mr. Demirel has emphasized the significant contributions of Turkey to this aid and stated that these aids will continue without interruption. According to Demirel, the aim of the aid is to maintain the world peace and to serve for the human wellfare ${ }^{32}$.

Furthermore Turkish Prime Minister made a very important meeting with the President Bush in Washington, during his visit to the United States on February 11-17. The main point of this meeting was the economic and political relations with the Independent States disintegrated from the USSR. Mr. Demirel has presented a plan of 13 articles to President Bush in his talk.According to the plan known as "Demirel's Plan" Turkey should be the "key country" of the aid chain from Western World to these countries. According to the plan, International commissions will be established in the field of education, economy, technology, security and the aids to such countries should be realized in the light of the decisions taken by these commissions. In application of this plan, accepted by the President Bush in principle, Turkey should undertake the role of "bridge". This project has a potential which will increase and reinforce Turkey's effectiveness both in the region and in the International platform, to a great extent.

A major development was attained in the relationships between Turkey and Caucasion and Central Asian Turki Republics during Prime Minister Demirel's official visits to these countries, between April 27 and May 3.

During the visit of Mr. Demirel, 41 agreements have been signed. The distribution of the agreements by these countries is as follows :

$\begin{array}{lr}\text { Uzbekhistan } & 8 \\ \text { Kırgzhistan } & 9 \\ \text { Kazakhistan } & 10 \\ \text { Turkmenhistan } & 10 \\ \text { Azerbaidzhan } & 4\end{array}$

Futhermore, 16 other agreements had already been signed with Azerbaidzhan. 
Also, these 41 agreements are d i iled into four sections :

1. Economic and financial subjects,

2. Transportaticiı inatters,

3. Flow of infortisition and ccoperation in telecommunication,

4. Educational ank cultural issues.

Some other importani step o.: Turkey towards the CIS is the creation of the Organization of Black Sea Econom is Cooperation (BSEC). Founding document of the BSEC which has also been initiated i I Istanbul on February 3. 1992, has been signed as the "Bosphorus Declaration" by the haids of state: and governments of the 11 founding states on June $25,1992$.

With the application of the froject of BSEC, a market of 400 million people (Which is much larger then EC mark:ti will be created. In this market the four freedoms will take place. In other words, persciss, goods, services and capital will move freely step by $\operatorname{step}^{33}$.

It is evident that BSEC: is not an cxperience of political integration as the European integration. Therefore, it is not coning into being as an alternative to EC. But this project will offer an opportunity to $i$ 's members foi a major cooperation and proximity.

After the process of changing vorrld balances, the importance of Turkey's strong and privileged location is confirmed. "he policies implemented by Turkey within the framework of all those recent develo ments will yicld most significant results regarding the international relations.

${ }^{33}$ Geray H., "Historical Sunumit for 1353 C", Cumbsriyet, Daily Newspaper, 24.6.1992. 